\title{
SALAZOPYRIN IN THE TREATMENT OF RHEUMATOID ARTHRITIS
}

\author{
BY \\ R. J. G. SINCLAIR \\ From the Rheumatic Unit, Northern General Hospital, Edinburgh \\ and \\ J. J. R. DUTHIE \\ From the Department of Medicine, University of Edinburgh
}

In several reports (1941a, b, 1942, 1944, 1948) published during recent years Professor Nanna Svartz has claimed good results in the treatment of rheumatic polyarthritis from the use of a sulphapyridine compound. The drug, which has been given the name salazopyrin, is obtained by the chemical combination of salicylic acid and sulphapyridine and has the formula 4-/pyridyl (2) amido sulphonyl/-3'-Carbody-4'-oxyazobenzene.

It is claimed that the drug has a specific affinity for connective tissue, where subsequent disintegration gives rise to amino-salicylic acid and sulphapyridine. Svartz (1948) believes that the essential lesion in rheumatic disease is located in connective tissue and is inflammatory in nature. On this basis she argues that drugs with an affinity for connective tissue are most likely to be of value in treatment. The value of salicylates in ameliorating the symptoms of rheumatic fever is accepted. Unless organisms are present in the inflamed connective tissue, the desirability of attaining a high local concentration of sulphapyridine is more in doubt. Few observers believe that there is such a dissemination of bacteria in rheumatic fever or in rheumatoid arthritis.

The initial dosage recommended by Svartz was $6 \mathrm{~g}$. in twenty-four hours. This was reduced to 1 to $1 \frac{1}{2} \mathrm{~g}$. daily as the condition improved. In chronic rheumatoid arthritis she advocates the use of the drug over a long period. Some of her patients have consumed 5,000 to $6,000 \frac{1}{2}-\mathrm{g}$. tablets in one to two years. Toxic effects are said to be relatively rare, the commonest being fever, skin rashes, nausea, and vomiting. These symptoms subside quickly when the drug is withdrawn.

Svartz divided her cases into acute and chronic rheumatic polyarthritis, and claimed that benefit was obtained in both instances. This classification makes it difficult to assess her results. For theo chronic group she also uses the term " chronico rheumatoid arthritis " so the effects of the drug inthis group will be considered in more detail.

JOINTS INVOLVED :

Key to Chart

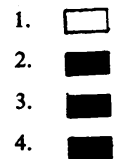

Joint not involved.

Pain, swelling, limitation of movement : active stage. 하

Residual damage, but no active inflammation : inactie

stage.

Moderate activity, intermediate between 2 and 3 .

U.S. = upper spine.

S. = shoulders.

L.S. = lower spine.

E. =elbows.

W. = wrists.

H. = hands and fingers.

H. = hips.

K. = knees.

A. =ankles

Current Status :

1. Return to full normal occupation.

2. Return to modified occupation or selected employment.

(a) Working and attending for out-patient treat ment.

3. Not working, attending for out-patient treatment.

(a) In-patient-attending physiotherapy department, and allowed out of hospital.

4. Ambulatory in the ward.

(a) Confined to bed, but allowed up to bathroom.

5. Completely confined to bed.

Clinical Assessment :

1. Joints : movement good, power good, no pain. $\mathrm{N}$ Health : satisfactory-eating and sleeping well. of

2. Joints: moderate limitation of movement, somes pain, power fair.

Health : good, but easily tired.

3. Joints: marked limitation of movement, pain swelling, power poor.

Health : fair, capacity for exercise strictly limited.

4. Joints : very little movement, pain, swelling, marked loss of power.

Health : poor, fatigue, anorexia, fever, loss of weight. 


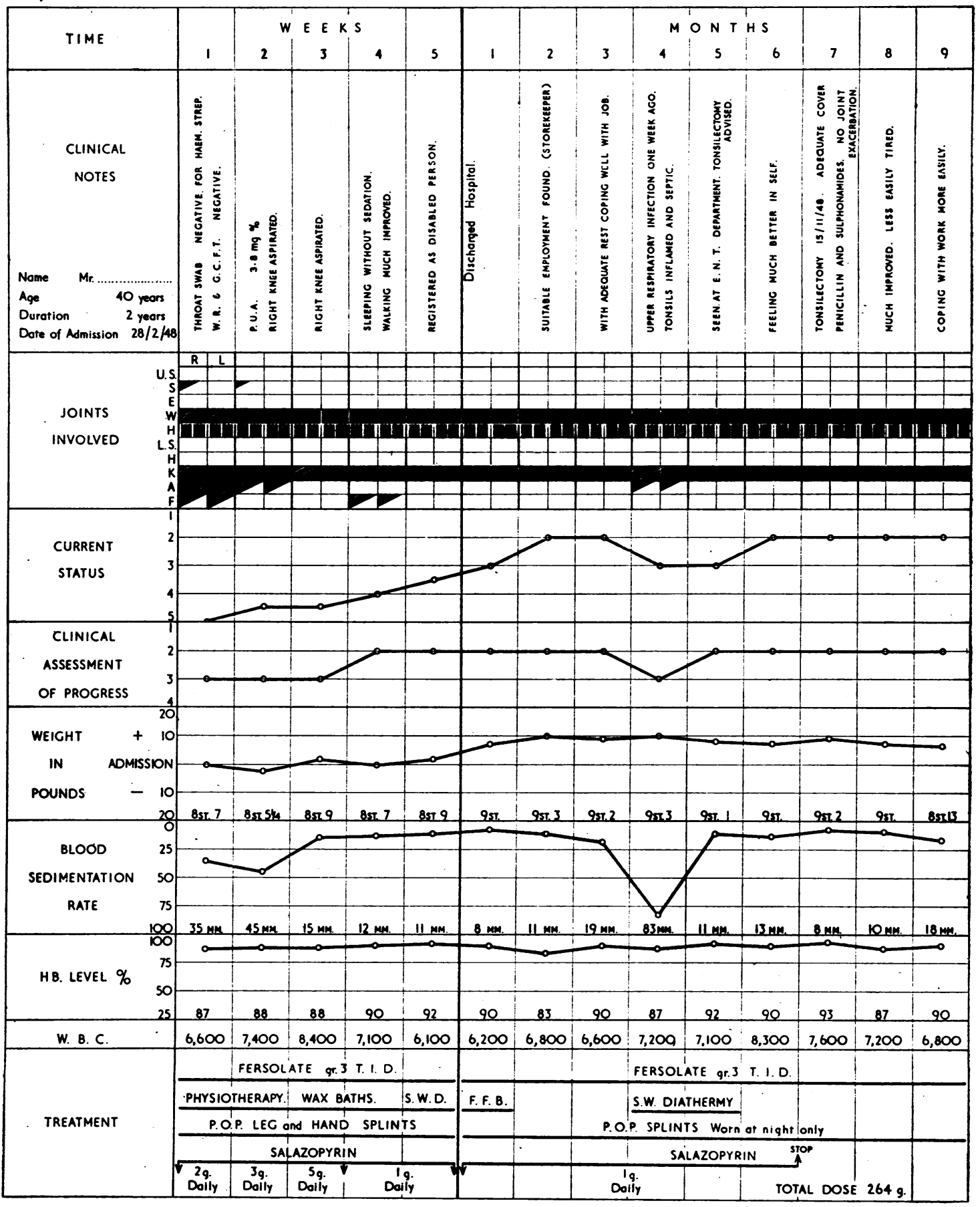


During the years $1941-45,475$ cases of the chronic type were given salazopyrin. The minimum period of follow-up was two years. Patients were sent a questionnaire and 307 replies were received. One hundred and ninety-four patients (63 per cent.) had recovered or showed improvement. In eighty-nine (29 per cent.) the condition was unchanged or had deteriorated. Twenty-four had died. The questionnaire revealed that many patients had failed to continue with treatment after discharge from hospital, but of the 16 per cent. who continued to take the drug for a lengthy period, three-quarters were cured or substantially improved.

Fletcher (1944) reported on the use of salazopyrin in five cases of rheumatic fever, one of gonococcal arthritis, two of acute infective arthritis, and six of chronic infective arthritis. In this last group only one patient was treated for as long as six months and the total dose was $180 \mathrm{~g}$. This patient and one other, treated for three months, stated that they felt better, but there was little clinical evidence of improvement and the blood sedimentation rate did not return to normal.

\section{The Present Investigation}

In view of the substantial claims made by Svartz as to the value of salazopyrin in chronic rheumatoid arthritis it was decided to submit the drug to further clinical trial. A supply of salazopyrin was obtained from Sweden through the courtesy of Professor Svartz, and twenty cases of rheumatoid arthritis were treated. In view of the difficulty in assessing the value of any form of therapy in a chronic disease without adequate controls, the results in these cases were compared with those obtained in a group receiving gold, and in a third group receiving no specific therapy. All sixty cases were treated initially as in-patients and all were subjected to the same basic regime of treatment in the rheumatic unit. This included rest in bed, dietary supplements, rest splints, physiotherapy, and remedial exercises. It is recognized that this regime alone will lead to substantial improvement in the majority of cases of rheumatoid arthritis, but it was felt that when the results in the three groups were finally compared in detail, some indication would be obtained as to whether salazopyrin had any specific effect on the disease. The inclusion of a group receiving gold therapy was considered desirable, as it allowed comparison with patients receiving a drug believed to be of real value in this disease.

The clinical details and laboratory investigations in each patient were entered on a chart specially designed for the purpose (see Figure). The patients were examined and assessed on each occasion by the same observer (R.J.G.S.). The key to the chart is given in full. It was felt that the routine charting of all relevant data at intervals both during in-patient treatment and during the follow-up period by one observer would enable the final assessment of patients in each of the three groups to be made with a reasonable degree of accuracy. The method will be modified and improved in the light of further experience.

The dose of salazopyrin used was initially that recommended by Svartz-6 $\mathrm{g}$. in twenty-four hours. Twelve of the first fourteen patients receiving $\vec{\circ}$ this amount showed toxic reactions within four to five days, varying from slight headache and nausea $\stackrel{\omega}{\circ}$ to high fever and rashes. Some showed red blood cells in the urine. The symptoms subsided immediately the drug was stopped. Five patients were given anthisan up to $800 \mathrm{mg}$. daily for several days, $\tilde{N}$ then full doses of salazopyrin were resumed. Toxic $\stackrel{N}{\sigma}$ reactions again developed in each of these cases. $\frac{}{I}$ In subsequent cases the initial dose was reduced to $2 \mathrm{~g}$. daily and increased gradually to $5 \mathrm{~g}$. daily. $\mathbb{D}$ On this regime toxic reactions were mild and infrequent. Patients were discharged from hospital on a mintenance dose of $1 \mathrm{~g}$. daily. Table 1 gives $\underset{\mathbb{D}}{\widetilde{D}}$ details of these patients. During their stay in hospital the data shown in the chart was noted $\vec{\varphi}$ at weekly intervals. After discharge patients reported to the follow-up clinic once a mont The same procedure was followed for the cases on gold and for those receiving no specific therapy. The group on gold all received a standard course, starting with four injections of $0.01 \mathrm{~g}$. myochrysin $\mathbb{\perp}$ at weekly intervals. The dose was then raised to $0.05 \mathrm{~g}$. weekly and maintained at that level till $1 \mathrm{~g}$. had been given. Injections had to be stopped in three cases because of mild toxic reactions.

All patients on discharge from hospital claimed to be substantially improved. A few of those on salazopyrin believed that they had definitely benefited from taking the drug. An analysis of the results (Table 2) shows that in sixteen cases on salazopyrin the clinical assessment on discharge from hospital had improved; fourteen had moved $\mathrm{O}$ up from grades 4 and 3 to grade 2, and two had reached grade 1 . On the final assessment, however, five had dropped back to grade 3.

Improvement was slightly better maintained in N those receiving gold, eighteen remaining in the two $N$ upper grades on final assessment. The results $\underset{\omega}{N}$ in the controls are almost identical with those on salazopyrin. Table 3 shows the haemoglobin levels in the three groups. The results are again slightly in favour of those patients receiving gold.

Analysis of blood sedimentation rates (Table 4) shows no significant differences between the three 
TABLE 1

\section{SALAZOPYRIN : DOSAGE AND LENGTH OF COURSE}

\begin{tabular}{|c|c|c|c|c|c|c|c|c|}
\hline No. & Sex & Age & $\begin{array}{l}\text { Duration of } \\
\text { symptoms in } \\
\text { years }\end{array}$ & $\begin{array}{l}\text { Total dose } \\
\text { (g.) }\end{array}$ & $\begin{array}{l}\text { Toxic } \\
\text { reactions }\end{array}$ & $\begin{array}{l}\text { Length of } \\
\text { course } \\
\text { (days) }\end{array}$ & $\begin{array}{l}\text { Stay in } \\
\text { hospital } \\
\text { (weeks) }\end{array}$ & $\begin{array}{l}\text { Follow-up } \\
\text { (months) }\end{array}$ \\
\hline 1 & M. & 48 & 0.5 & 33 & Rash, fever & 14 & 15 & 11 \\
\hline 2 & M. & 24 & 19 & 60 & Rash, nausea & 26 & 12 & 6 \\
\hline 3 & F. & 39 & 8 & 88 & Depression & 30 & 11 & 10 \\
\hline 4 & F. & 43 & 2 & 240 & - & 180 & 6 & 10 \\
\hline 5 & M. & 60 & 20 & 340 & - & 135 & 21 & 6 \\
\hline 6 & F. & 43 & 10 & 35 & Rash, nausea & 15 & 5 & 9 \\
\hline 7 & M. & 41 & $1 \cdot 5$ & 253 & - & 98 & 18 & 6 \\
\hline 8 & F. & 36 & $1 \cdot 25$ & 74 & Rash, nausea & 69 & 4 & 9 \\
\hline 9 & F. & 41 & 8 & 51 & Nausea & 40 & 5 & 9 \\
\hline 10 & F. & 46 & 0.5 & 80 & - & 30 & 10 & 7 \\
\hline 11 & M. & 46 & 2 & 181 & - & 97 & 11 & 3 \\
\hline 12 & F. & 38 & 21 & 203 & - & 74 & 11 & 7 \\
\hline 13 & M. & 35 & 7 & 86 & - & 60 & 14 & 5 \\
\hline 14 & F. & 57 & 3 & 105 & - & 52 & 8 & 6 \\
\hline 15 & M. & 35 & 1.5 & 126 & - & 49 & 9 & 6 \\
\hline 16 & M. & 40 & 0.16 & 135 & - & 63 & 6 & 6 \\
\hline 17 & M. & 51 & 0.33 & 112 & - & 58 & 5 & 5 \\
\hline 18 & F. & 50 & 1.5 & 85 & - & 42 & 4 & 5 \\
\hline 19 & M. & 23 & 3 & 116 & - & 35 & 9 & 3 \\
\hline 20 & F. & 55 & 5 & 50 & - & 30 & 21 & 2 \\
\hline
\end{tabular}

TABLE 2

ANALYSIS OF RESULTS

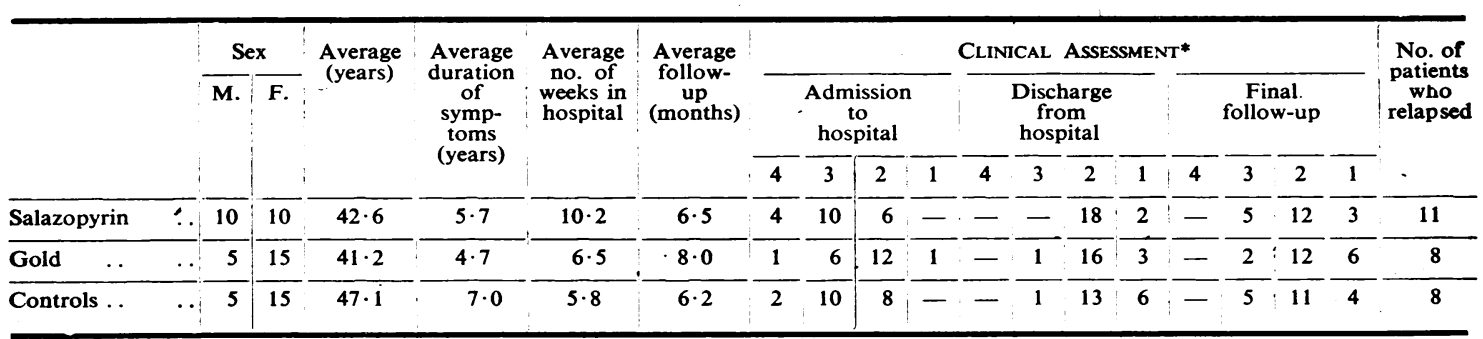


TABLE 3

HAEMOGLOBIN ESTIMATION

\begin{tabular}{|c|c|c|c|c|c|c|c|c|c|c|}
\hline & & \multicolumn{3}{|c|}{$\begin{array}{l}\text { Admission } \\
\text { to hospital }\end{array}$} & \multicolumn{3}{|c|}{$\begin{array}{l}\text { Discharge } \\
\text { from hospital }\end{array}$} & \multicolumn{3}{|c|}{$\begin{array}{l}\text { Final } \\
\text { follow-up }\end{array}$} \\
\hline & & $\begin{array}{c}60- \\
70 \%\end{array}$ & $\begin{array}{c}71- \\
80^{\circ}\end{array}$ & $\begin{array}{l}81- \\
100^{\circ}\end{array}$ & $\begin{array}{l}60- \\
70 \%\end{array}$ & $\begin{array}{c}71- \\
80^{\circ}\end{array}$ & $100^{\circ}$ & $\begin{array}{l}60- \\
70 \%\end{array}$ & $\begin{array}{l}71- \\
80^{\circ}\end{array}$ & $\begin{array}{l}81- \\
100^{\circ}\end{array}$ \\
\hline Salazopyrin & . & 3 & 1 & 16 & - & 2 & 18 & - & 3 & 17 \\
\hline Gold & $\ldots$ & 一 & 4 & 16 & - & 2 & 18 & - & 1 & 19 \\
\hline Controls & . & - & 3 & 17 & - & - & 20 & - & 3 & 17 \\
\hline
\end{tabular}

TABLE 4

B.S.R. ESTIMATION

\begin{tabular}{|c|c|c|c|c|c|c|c|c|c|}
\hline & \multicolumn{3}{|c|}{$\begin{array}{l}\text { Admission } \\
\text { to hospital }\end{array}$} & \multicolumn{3}{|c|}{$\begin{array}{c}\text { Discharge } \\
\text { from hospital }\end{array}$} & \multicolumn{3}{|c|}{$\begin{array}{c}\text { Final } \\
\text { follow-up }\end{array}$} \\
\hline & $\begin{array}{c}\text { Normal } \\
0-10\end{array}$ & $\begin{array}{c}\text { Moder- } \\
\text { ately } \\
\text { raised } \\
11-40\end{array}$ & $\begin{array}{l}\text { Mark- } \\
\text { edly } \\
\text { raised } \\
41-100\end{array}$ & $\begin{array}{c}\text { Normal } \\
0-10\end{array}$ & $\begin{array}{l}\text { Moder- } \\
\text { ately } \\
\text { raised } \\
11-40\end{array}$ & $\begin{array}{l}\text { Mark- } \\
\text { edly } \\
\text { raised } \\
41-100\end{array}$ & Normal & $\begin{array}{c}\text { Moder- } \\
\text { ately } \\
\text { raised } \\
11-40\end{array}$ & $\begin{array}{c}\text { Mark- } \\
\text { edly } \\
\text { raised } \\
41-100\end{array}$ \\
\hline Salazopyrin & 1 & 13 & 6 & 4 & 8 & 8 & 5 & 10 & 5 \\
\hline Gold & 2 & 11 & 7 & - & 12 & 8 & 5 & 12 & 3 \\
\hline Controls & 3 & 10 & 7 & 6 & 12 & 2 & 5 & 10 & 5 \\
\hline
\end{tabular}

groups. The B.S.R. remained raised in fifteen cases in each. Table 5 shows the proportions of patients who gained or lost weight during their stay in hospital and during the follow-up period. The results again favour the patients on gold.

TABLE 5

\section{FLUCTUATION IN WEIGHT}

\begin{tabular}{|c|c|c|c|c|c|c|}
\hline & \multicolumn{3}{|c|}{ In hospital } & \multicolumn{3}{|c|}{ Final follow-up } \\
\hline & $\begin{array}{l}\text { Gain } \\
\text { (over } \\
2 \text { lb.) }\end{array}$ & $\begin{array}{c}\text { Static } \\
\text { (less } \\
\text { than } \\
2 \mathrm{lb} . \\
\text { gain } \\
\text { or } \\
\text { loss) }\end{array}$ & $\begin{array}{l}\text { Loss } \\
\text { (over } \\
2 \text { lb.) }\end{array}$ & $\begin{array}{l}\text { Gain } \\
\text { (over } \\
2 \text { lb.) }\end{array}$ & $\begin{array}{c}\text { Static } \\
\text { (less } \\
\text { than } \\
2 \text { lb. } \\
\text { gain } \\
\text { or } \\
\text { loss) }\end{array}$ & $\begin{array}{c}\text { Loss } \\
\text { (over } \\
2 \text { lb.) }\end{array}$ \\
\hline Salazopyrin & 12 & 3 & 5 & 6 & 5 & 9 \\
\hline Gold & 8 & 6 & 6 & 5 & 8 & 7 \\
\hline Controls .. & 6 & 10 & 4 & 8 & 1 & 11 \\
\hline
\end{tabular}

\section{Discussion}

In the final analysis of results in the three groups of patients, those receiving gold, in addition to the basic regime of treatment, appeared to benefit the most. There is no appreciable difference between the group receiving salazopyrin and those given no specific therapy, in spite of the fact that the patients receiving salazopyrin were retained in hospital longer for the purposes of the experiment. The scope of the clinical trial was limited but it is felt that, had salazopyrin been of any real value in modifying the course of the disease, some indication of its action in this respect would have been obtained. It might be objected that the total dose and length of course were not those recommended in the original reports, but the incidence of toxic reactions was unduly high when large initial doses were given. With regard to the length of course, it is generally admitted that if any single method of therapy is continued for long enough in rheumatoid arthritis, it is likely that a natural remission of the disease will occur, and credit may be wrongly given to that particular remedy. 
The theoretical basis for the use of salazopyrin in rheumatoid arthritis-that it has a specific affinity for connective tissue where it disintegrates into sulphapyridin and aminosalicylic acid-cannot be regarded as sound. Salicylates have no specific effect in this disease, no has any member of the sulpha group of drugs. Penicillin and streptomycin have been equally ineffective. This is not surprising as few observers now believe that living organisms play a direct part in the production of the changes in connective tissue.

\section{Summary}

1. The drug salazopyrin has been used in the treatment of twenty cases of rheumatoid arthritis.

2. The results obtained have been compared with those in twenty cases treated with gold and twenty cases in whom no specific therapy was given.

3. All three groups were studied as in-patients and followed up for six to eight months.

4. All three groups underwent the same basic regime of treatment.

5. The method of case-recording is described.

6. Salazopyrin does not appear to be of any specific value in the treatment of this disease.
The authors wish to express their gratitude for the help given by the medical and nursing staff of the Rheumatic Unit, Northern General Hospital, Edinburgh.

\section{REFERENCES}

Fletcher, E. (1944). Med. World, 60, 697.

Svartz, N., and Kallner, S. (1940). Nord. Med., 8, 1935.

- (1941a). Nord. M d., 9, 554.

(1941b). Ibid., 11, 2261.

(1942). Acta med. scand., 110, 577.

(1944). Nord. Med., 23, 1713.

(1948). Ibid., 37, 299.

(1948). Rheumatism, 4, 180.

, Kallner, S., and Helander, S. (1945). Nord. Med., $25,211$.

\section{Salazopyrine dans le Traitement de l'Arthrite} Rhumatismale

\section{RÉSUMÉ}

Le médicament salazopyrine fut employé dans le traitement de vingt cas d'arthrite rhumatismale. Les résultats furent comparés avec ceux obtenus dans vingt cas soumis à la chrysothérapie et dans vingt cas sans aucun traitement spécifique. Les malades des trois groupes étudiés se trouvaient hospitalisés et ils furent surveillés pendant six à huit mois. Les trois groupes furent soumis au même régime fondamental de traitement. On décrit la méthode suivie pour compiler le dossier clinique des malades.

La salazopyrine ne semble avoir aucune valeur spécifique dans le traitement de cette maladie. 